\title{
Quaternary Volcanic Ashes in the Narugo and Onikōbe Volcanic Areas ${ }^{1)}$
}

\author{
Iwao MURAYAMA ${ }^{2)}$
}

\section{Introduction}

Volcanic ashes are dusty to sandy fragments (less than 4 millimeters in grain size), consisting either of comminuted magma or of pulverized rock material from the vent walls, or, as in the majority of cases, a mixture of both.

A soil is rather the product of development, or evolving from a parent material, which is the mantle rock, or regolith, and volcanic fragmental material especially volcanic ash in volcanic areas.

Newly deposited glassy ash is generally blackish or grayish in color, however weathers very quickly in Japan. Climate affects the weathering and leaching of the volcanic ashes through its seasonal variations in temperature and rainfall. Prevailing high temperatures promote rapid chemical change, such as oxidation of divalent iron in the volcanic ashes, and cold slows it down. Iron which is included in a particle of the ashes as a chemical composition has been changed by oxidation, and thus exhibits a brown soil color. Also, the alteration of the volcanic ashes has been accelerated by the solfataric action and subterranean heat etc. in geothermal areas.

In this paper is described the distribution, state of accumulation and some characteristics of the Quaternary volcanic ashes of the Narugo and Onikōbe volcanic areas.

\section{Outline of the areas}

The Narugo and Onikōbe volcanoes are situated in the northwestern part of Miyagi Prefecture, in the northeastern section of Japan. They are easily accessible from the Narugo Spa of the Rikuu-tō-sen Railroad Line.

\section{A. The Narugo volcanoes}

The Narugo volcanoes are composed of three crests, named Oga-dake (462 m), Kurumiga-dake (461.4 m) and Toriyaga-dake $(396 \mathrm{~m})$.

The crests are of tholoide shape. The lava of the volcanoes consists primarily of dacite which is called the Kata-numa lava (Onuki and Kitamura, 1962). This lava unconformably covers the upper part of the Narugo formation which consists of conglomerate, sandstone and siltstone. The Narugo formation is assigned to early Pleistocene. The geological age of the first eruption of the volcanoes may be late Pleistocene as judged from the relationship between the lava and Narugo formation.

The lake "Kata-numa" is surrounded by three crests. The acidity of the water of Kata-numa is the strongest in Japan, showing $\mathrm{pH} 2.7$ of the water, and now sulfur is being mined from the bottom of the lake.

It is unknown how many times volcanic activity took place in the area of Kata-numa during historic time. But, it is only known that small activities occurred during the Jowwa era (A. D. 834-848). These were preceded by a rumbling noise (Miyagi-ken High School's Science Study Organization, 1963).

The vegetation of the crests consists of grasses such as Graminaceae, Miscanthus etc. Pine-tree and miscellaneous trees are now growing at the foot of the crests.

\section{B. The Onikōbe volcanoes}

The Onikōbe volcanoes rise up in the Onikōbe basin which is situated in the north of the Narugo volcanoes. The volcanoes consist of Arao-dake (984.2 $\mathrm{m})$, San-nō-mori $(938.4 \mathrm{~m})$ and Takahinata-yama (769.1 m).

The Onikōbe basin was formerly called a caldera from the view point of topography (Tsujimura, 1942), Geology (Kobayashi, 1929; Nakamura, 1956) and petrology (Katsui, 1955). However, the original form of the basin is supposed to have been formed by the crustal deformation, and formed a paleo-lake. The lacustrine sediments deposited in this paleo-lake (Omoto, 1964).

The basin is surrounded by such mountains as Kobuchi-yama (1261.7 m), Katakura-mori $(1040.6 \mathrm{~m})$, Sugane-dake (1243 m), Takenoko-mori (1125.4 m), Suzukura-mori (962 m), Ohira-yama (779.6 m), Ōshibayama $(1083.2 \mathrm{~m})$ and Koshiba-yama $(1055.8 \mathrm{~m})$ etc. These mountains consist of green tuff and granodiorite etc. and rise up to about 1000 meters above sea level.

Arao-dake is situated nearly in the central part of the basin, and Takahinata-yama is on the southeastern side of Arao-dake. Arao-dake consists of hypersthene-

1) 1969. 1.8. 受付

2) Töhoku-gakuin University（東北学院大学） 
andesite and augite-andesite, whereas San-nō-mori and Takahinata-yama are built of dacite.

Hot springs are extremely widespread in the Narugo and Onikōbe volcanic areas. Intermittent hot springs have been known in the Onikōbe volcanic area, where they are called geysers. After ejecting small amounts of waters, jets of steam throw out with great violence. Boiling mud pits are found at Katayama-jigoku. Hot steam gases break through the geothermal ground at Katayama-jigoku, Megama-Ogama and Arayu etc. Sulfur was mined at Arayu.

Virtually all of the Onikōbe volcanic area is mainly covered with beech-trees, the exception being the geothermal areas.

\section{Formation of the volcanic bodies}

\section{A. The Narugo volcanoes}

The volcanic ejecta which formed the three crests is mainly of lava. The lava of Oga-dake and Kurumiga-dake consist of dacite, however, the lava of Toriyaga-dake is hypersthene-bearing plagio-ryolite (Ikeda, 1942).

This lava is underlain by the upper part of the Narugo formation which consist of conglomerate, sandstone and siltstone etc. Also, the outcrops of granodiorite are seen in the cliffs along the Arao River (Eai River) near the Narugo Dam in the northwestern part, or in the cliffs of the southern part of the volcanoes. They are well exposed in the dissected cliff extending northwestward or southward from the volcanoes. The Tertiary formation can be seen to cover the eroded surface of granodiorite of which age is considered to be Pre-tertiary.

The lava (dacite) of Kata-numa which consists of Oga-dake and Kurumiga-dake has a dark gray color and assumes a gray or reddish brown color on weathered surface, and its phenocrysts are composed of quartz and pyroxene.

Round gravel layers which are supposed to be lacustrine deposits are found in the mudflow materials, or underly the mudflow materials in the area. Also, tuff with laminations is recognized in the cliff of Kata-numa. Hence, the first explosion is presumed to have been occurred on the lacustrine deposits. The explosion crater which is called Kata-numa is supposed to have been formed in the paleo-lake. The original form of the paleo-lake was formed by the crustal deformation. The Kata-numa, which is now filled with water, has a nearly circular or a quadrilateral form with a diameter of about 450 meters.

Remarkable exposures of the mudflow materials are seen in the cliffs of the quarry near Kata-numa and also along the Arao River. The mudflow materials consisted of subangular or angular dacite blocks and lapilli of 0.1 centimeters to 2 meters in diameter, with reddish brown (5YR5/8) volcanic ash as matrix. The blocks have such varying colors as gray, dark gray and light gray etc. The mudflow materials accumulated to a thickness of more than ten meters. This mudflow named the Kata-numa mudflow.

The Narugo mudflow seems to have poured out from the source which is supposed to have succesively supplied from the Kurumiga-dake area. It flowed down northwards widely over the area including Narugo Town, probably in contact with the Kata-numa mudflow. The mudflow materials consisted of subangular dacite lapilli and blocks of 1-60 centimeters in diameter and yellow brown volcanic ash as matrix. The exposures are seen along the Arao River and some cliffs in the Narugo Town area.

\section{B. The Onikōbe volcanoes}

The volcanic products which form the main bodies of each volcano consist mainly of lava. The first eruption which formed the main bodies of the Onikōbe volcanic group is supposed to have begun from Arao-dake, then moved to San-nọ-mori, and finally formed Takahinata-yama. The order of eruption is divided into volcanic mudflow, Iwana"zawa lava, San-nō-mori-zawa lava in the order stated (Katō and Shimada, 1953).

The geological age of the first volcanic activity in the basin is supposed to be from Pliocene to Pleistocene, and erupted lava and agglomerate from Arao-dake on the lacustrine deposits. And Takahinatayama is presumed to have erupted during the age Pleistocene to Holocene according to Omoto (1964). The terrace plain were formed by the Arao River and its tributaries.

\section{Deposition of the volcanic ashes}

\section{A. The Narugo volcanoes}

The volcanic ashes which erupted from the Narugo volcanoes on the ground surface are divided into the brown and black volcanic ashes. The brown (yellow brown or reddish brown) volcanic ash was deposited by the volcanic activities after the mudflow areas were formed. The volcanic ashes after being erupted were changed into the brown volcanic ash by weathering and oxidation of the iron in particles of the ash. Namely, the soil color of the volcanic ashes was changed into a brown color. At present, the soil color of the ashes is indicated mainly in yellow brown 10YR $5 / 6$ or red brown $5 Y$ R $5 / 8$ of the standard soil color chart. This brown volcanic ash which is widely spreaded in this area, is underlain by mudflow materials and covered by the black volcanic ash. 


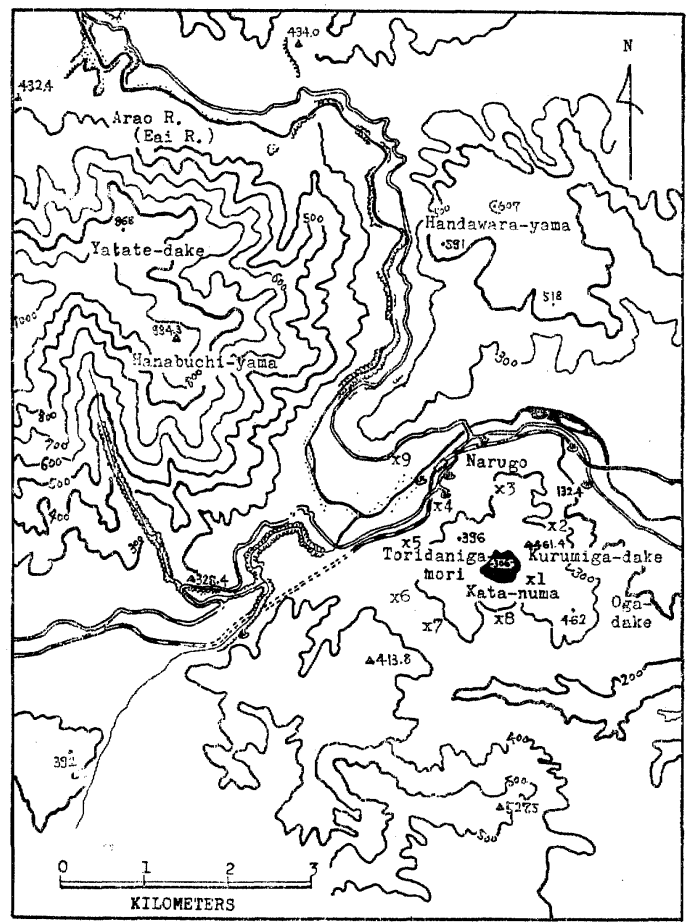

Fig. 1. Localities of Columnar Sections in the Narugo Volcanic Area.

The particles of this ash are leached to a advanced degree. However, augite, hypersthene, hornblende and magnetite are found microscopically. According to the report by Ishida (1965), such a volcanic ash is distributed on the Osaki plain in the southeastern part of Narugo Town.

After the deposition of the brown volcanic ash, the black volcanic ash accumulated on the brown volcanic ash layer. The black volcanic ash accumulated $0-10$ centimeters in thickness in the area within a radius of about 2 kilometers from Kata-numa. The origin of this ash is supposed to be the explosion craters in the Narugo volcanoes.

A few mineral fragments such as plagioclase, pyroxene and quartz etc. are recognized in the black volcanic ash.

\section{B. The Onikōbe volcanoes}

The brown volcanic ash is widely deposited on the outer mountains and inner area of the basin, and underlies the black volcanic ash. The soil color of this ash is mainly indicated in yellow brown 10YR $5 / 6$ of the standard soil color chart. This ash is $1-20$ meters in thickness in the basin.

However, this ash layer is accumulated thickly, and includes plant leaves in the Katayama-jigoku and Arayu areas. In view of this fact, this ash may have

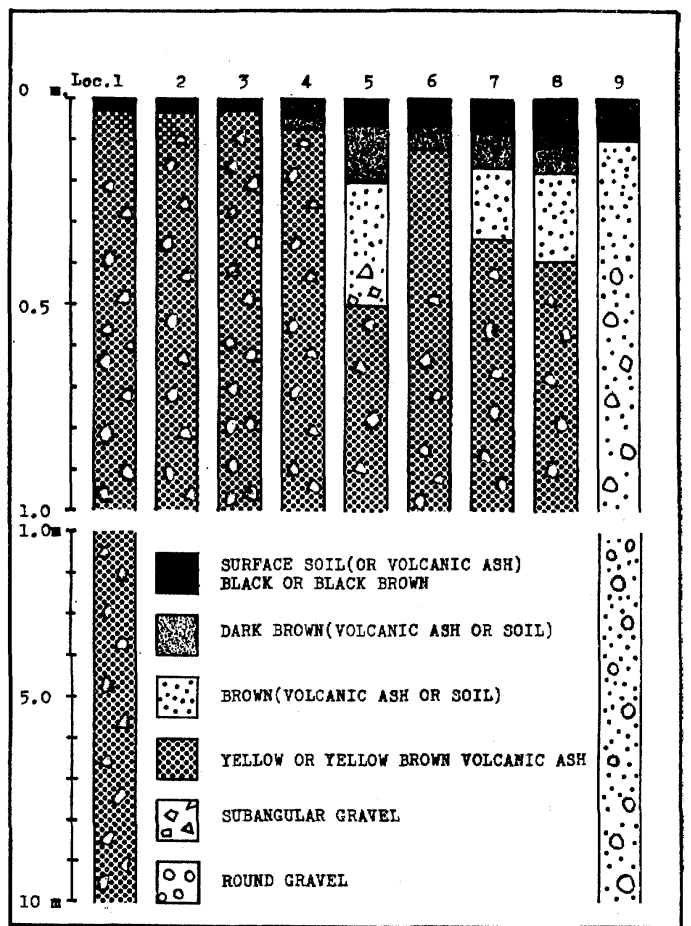

Fig. 2. Columnar Sections in the Narugo Volcanic Area.

deposited in the paleo-lake of the areas.

After the deposition of the brown volcanic ash, the black volcanic ash accumulated on the brown volcanic ash layer. The thickness of this ash layer is 10 centimeters to 10 meters in the basin.

\section{Some characteristics of the volcanic ashes}

\section{A. The Narugo volcanic area}

The black soil color of the ash is presumed to be due to the presence of colored minerals and humus. There is recognized a few mineral fragments in the black volcanic ash compared with the volcanic ashes of the Zaō area (Murayama, 1966).

The mineral components of the brown volcanic ash are progressed in degree of leaching and the state of clay formation. The mineral fragments can not be seen in the brown volcanic ash, and include less than 10 percent of humus.

However, a few mineral fragments are recognized in the black volcanic ash, and also include more than 20 percent of humus.

The acidity of the ashes is $\mathrm{pH} 3.9 \sim 4.9\left(\mathrm{H}_{2} \mathrm{O}\right)$ and $3.4 \sim 3.9$ (KCl). This soil acidity is very lower in. value compared with other volcanic ashes investigatep 


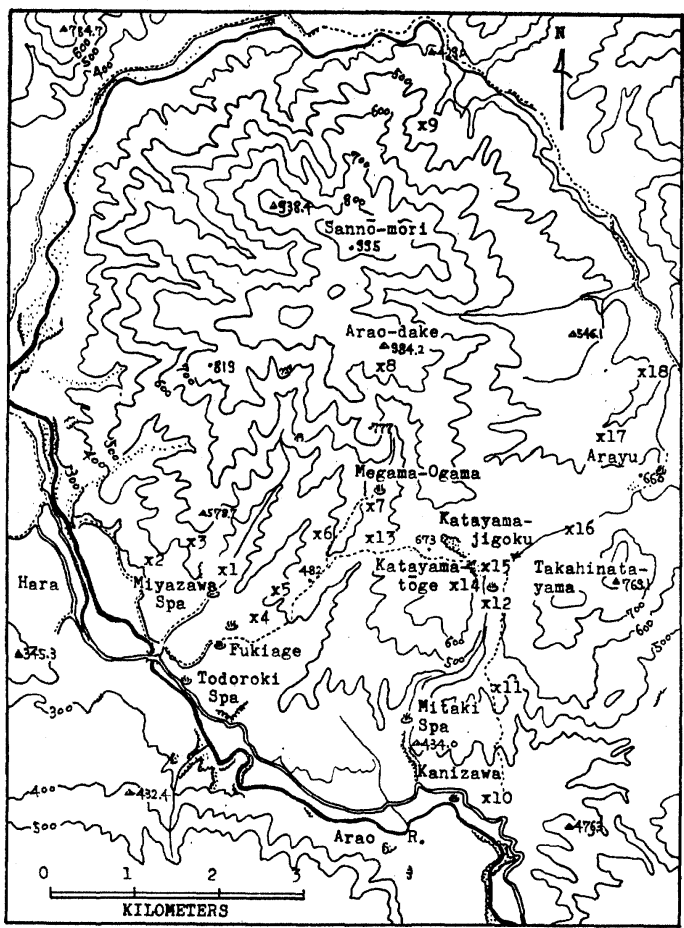

Fig. 3. Localities of Columnar Sections in the Onikōbə Volcanic Area.

\section{B. The Onikōbe volcanic area}

The particles of the black and brown volcanic ashes in the Oniköbe volcanic area are progressed in leaching, and no mineral crystal are recognized under the polarized microscope.

The black volcanic ash includes $20 \sim 30$ percent of humus, this being richer compared with the Zao,
Bandai and Iwate volcanic ashes. However, the brown volcanic ash of this area includes $3 \sim 10$ percent of humus, this being less compared with the black volcanic ash. The acidity of the black ank brown volcanic ashes are $\mathrm{pH} 4 \sim 6\left(\mathrm{H}_{2} \mathrm{O}\right)$ and $\mathrm{pH} 4 \sim 5.5$ (KCl).

Under the polarized microscope, no mineral fragment are recognized in the specimens of the black and brown volcanic ashes. This reason is supposed that the alteration of the volcanic ashes has been accelerated by the subterranean heat and solfatarie action etc.

\section{Relationships between the volcanic ashes and terrace plains}

\section{A. Narugo volcanic area}

Several levels of erosional surfaces and fluviatile terrace surfaces are formed along the Arao River. These terrace surfaces are divided into I, IIa, IIb, III, IV and V surfaces.

I surface This surface is the present river bed and flood plain along the Arao River.

IIa surface This surface is the latest terrace plain. The relative height of this terrace plain is $5 \sim 20$ meters from the present river bed. The materials of the terrace deposits consist of round gravels, subangular gravels, sand and clay. The gravels of these deposits are originated from the lava and block of the Narugo volcanoes.

IIb surface This surface as the fourth terrace plain spreads along the Arao River, at the surface of $100 \sim 200$ meters above sea level. The relative height of the surface is $20 \sim 40$ meters from the present river bed. The subangular gravels of this terrace deposits are supposed to have been originated from the lava

Table 1. Some characteristics of the volcanic ashes in the Narugo volcanic area

\begin{tabular}{|c|c|c|c|c|c|c|c|c|c|}
\hline \multirow{2}{*}{$\begin{array}{l}\text { Locali- } \\
\text { ties }\end{array}$} & \multirow{2}{*}{$\begin{array}{c}\text { Depth } \\
\text { from the } \\
\text { surface } \\
(\mathrm{cm})\end{array}$} & \multirow[b]{2}{*}{ Soil color } & \multicolumn{2}{|c|}{$\begin{array}{c}\mathrm{pH} \text { (by glass } \\
\text { electrode) }\end{array}$} & \multirow[b]{2}{*}{$\underset{(\%)}{\text { Humus }}$} & \multicolumn{4}{|c|}{ Mechanical analysis (\%) } \\
\hline & & & $\mathrm{H}_{2} \mathrm{O}$ & $\mathrm{KCl}$ & & $\begin{array}{l}\text { Coarse sand } \\
(2-0.2 \mathrm{~mm})\end{array}$ & $\begin{array}{c}\text { Fine sand } \\
(0.2- \\
0.02 \mathrm{~mm})\end{array}$ & $\begin{array}{l}\text { Silt } \\
(0.02- \\
0.002 \mathrm{~mm})\end{array}$ & $\begin{array}{c}\text { Clay } \\
(<0.002 \mathrm{~mm})\end{array}$ \\
\hline \multirow[t]{2}{*}{2} & $0 \sim 2$ & $\begin{array}{l}\text { Black } \\
7.5 \mathrm{YR} 2 / 2\end{array}$ & 3.9 & 3.6 & 21.3 & 6.5 & 16.5 & 48.0 & 29.0 \\
\hline & $2 \sim 10$ & $\begin{array}{l}\text { Yellow brown } \\
10 Y R 5 / 6\end{array}$ & 4.0 & 3.9 & 21.7 & 13.6 & 40.5 & 26.4 & 19.5 \\
\hline \multirow{4}{*}{5} & $0 \sim 8$ & $\begin{array}{l}\text { Black } \\
\text { 10YR2/1 }\end{array}$ & 4.8 & 3.7 & 21.2 & 10.5 & 16.0 & 12.5 & 61.0 \\
\hline & $8 \sim 20$ & $\begin{array}{l}\text { Dark brown } \\
7.5 Y R 3 / 4\end{array}$ & 4.7 & 3.9 & 9.1 & & & & \\
\hline & $20 \sim 50$ & $\begin{array}{l}\text { Brown } \\
7.5 Y R 4 / 6\end{array}$ & 4.7 & 3.9 & 8.4 & & & & \\
\hline & $50 \sim$ & $\begin{array}{l}\text { Yellow brown } \\
10 Y R 5 / 6\end{array}$ & 4.9 & 3.4 & 0.9 & & & & \\
\hline
\end{tabular}




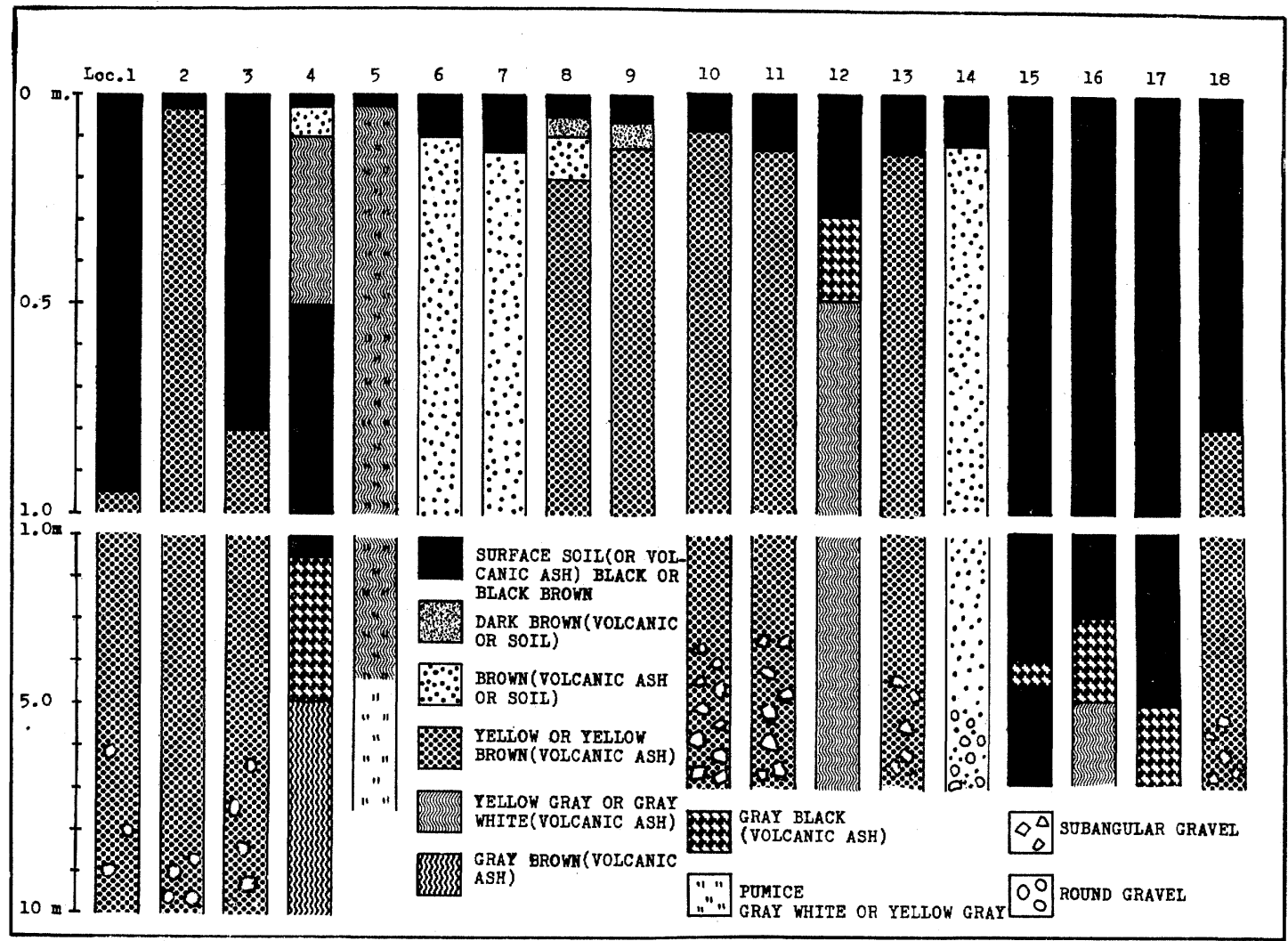

Fig. 4. Columnar Sections in the Onikōbe Volcanic Area.

Table 2. Some characteristics of the volcanic ashes in the Onikobe volcanic area

\begin{tabular}{|c|c|c|c|c|c|c|c|c|c|}
\hline \multirow{2}{*}{$\begin{array}{c}\text { Locali- } \\
\text { ties }\end{array}$} & \multirow{2}{*}{$\begin{array}{l}\text { Depth } \\
\text { from the } \\
\text { surface } \\
(\mathrm{cm})\end{array}$} & \multirow{2}{*}{ Soil color } & \multicolumn{2}{|c|}{$\begin{array}{l}\mathrm{pH} \text { (by glass } \\
\text { electrode) }\end{array}$} & \multirow{2}{*}{$\underset{(\%)}{\text { Humus }}$} & \multicolumn{4}{|c|}{ Mechanical analysis (\%) } \\
\hline & & & $\mathrm{H}_{2} \mathrm{O}$ & $\mathrm{KCl}$ & & $\begin{array}{l}\text { Goarse sand } \\
(2-0.2 \mathrm{~mm})\end{array}$ & $\begin{array}{c}\text { Fine sand } \\
(0.2- \\
0.02 \mathrm{~mm})\end{array}$ & $\begin{array}{l}\text { Silt } \\
(0.02- \\
0.002 \mathrm{~mm})\end{array}$ & $\begin{array}{c}\text { Clay } \\
(<0.002 \mathrm{~mm})\end{array}$ \\
\hline \multirow{4}{*}{8} & $0 \sim 7$ & $\begin{array}{l}\text { Black brown } \\
7.5 Y R 3 / 2\end{array}$ & 4.9 & 4.1 & 28.3 & 9.0 & 7.5 & 18.5 & 65.0 \\
\hline & $7 \sim 10$ & $\begin{array}{l}\text { Dark brown } \\
7.5 \text { YR } 5 / 8\end{array}$ & 5.2 & 5.5 & 17.7 & 8.5 & 6.5 & 18.5 & 66.5 \\
\hline & $10 \sim 20$ & $\begin{array}{l}\text { Light brown } \\
7.5 \text { YR } 5 / 8\end{array}$ & 5.0 & 4.6 & 9.8 & 10.0 & 7.5 & 6.5 & 76.0 \\
\hline & $20 \sim$ & $\begin{array}{l}\text { Yellow brown } \\
\text { 10YR5 } 6\end{array}$ & 5.9 & 5.0 & 3.2 & 4.5 & 3.0 & 2.5 & 90.0 \\
\hline \multirow[t]{2}{*}{10} & $0 \sim 5$ & $\begin{array}{l}\text { Black brown } \\
7.5 Y R 3 / 2\end{array}$ & 4.5 & 4.0 & 23.7 & 10.0 & 8.6 & 17.4 & 64.0 \\
\hline & $5 \sim$ & $\begin{array}{l}\text { Yellow brown } \\
\text { 10YR } 5 / 6\end{array}$ & 5.6 & 4.7 & 6.8 & 8.5 & 22.0 & 27.5 & 42.0 \\
\hline
\end{tabular}

of the Narugo volcanoes.

III surface This surface as the third terrace plain spreads along the Arao River, at the surface of 140 240 meters above sea level. The relative height of this surface is $40 \sim 60$ meters from the present river bed.

IV surface This surface as the second terrace plain spreads in the western side and southeastern 
side of the Narugo volcanoes, at the surface of 150 200 meters above sea level. The relative height of this plain is $60 \sim 90$ meters from the present river bed. The terrace deposits are consisted of subangular gravels.

V surface This surface as the first terrace plain spreads widely in the surrounding area of the Narugo volcanoes and in the area of the left bank of the Arao River, at the surface of 200-350 meters above sea level.

The brown volcanic ash accumulated on the hills, III, IV and V surfaces. However, only the upper part of the brown volcanic ash layer covers IIa and IIb surfaces. And the black volcanic ash accumulates on the brown volcanic ash layer.

B. The Onikōbe volcanic area

The topographical surfaces in the Onikōbe volcanic area are divided into I, II, III and IV surfaces.

I surface. This surface is the present river bed and flood plain of the upper stream of the Arao River and Ikusa-zawa.

II surface This surface is the latest terrace plain. The relative height of the surface is $10 \sim 40$ meters from the present river bed. The materials of the terrace deposits consist of round gravels, subangular gravels of granodiorite and green tuff with clay.

III surface This surface is the higher terrace plain. The relative height of the surface is about 50 meters from the present river bed. The materials of the terrace deposits consist of round and subangular gravels of granodiorite, andesite and green tuff etc. These gravels are of 3 centimeters to 1 meter in diameter, with sand and clay. The surface is covered by the brown volcanic ash layer of $0.5 \sim 5$ meters in thickness.

IV surface The relative height of the surface is

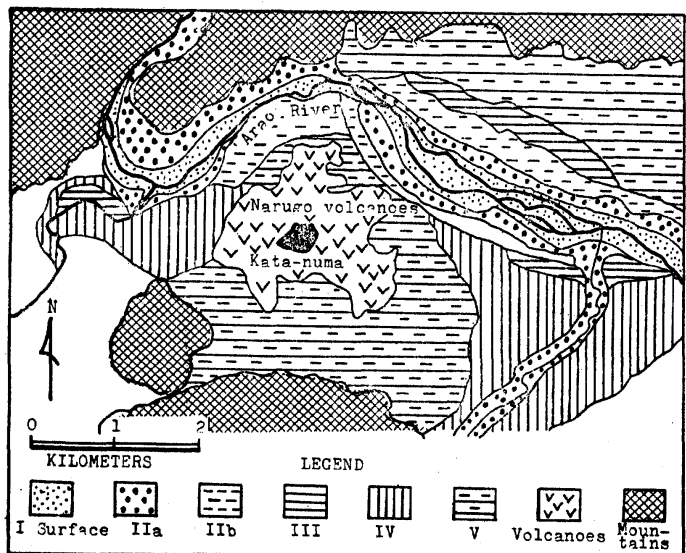

Fig. 5. Geomorphological Map of the Narugo Volcanic Area.

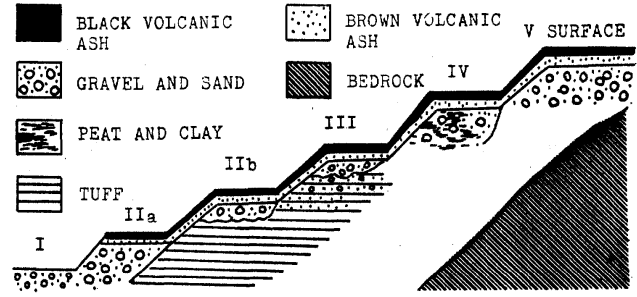

Fig. 6. Relationships between the Volcanic Ashes and Topographical Surfaces in the Narugo Volcanic Area.

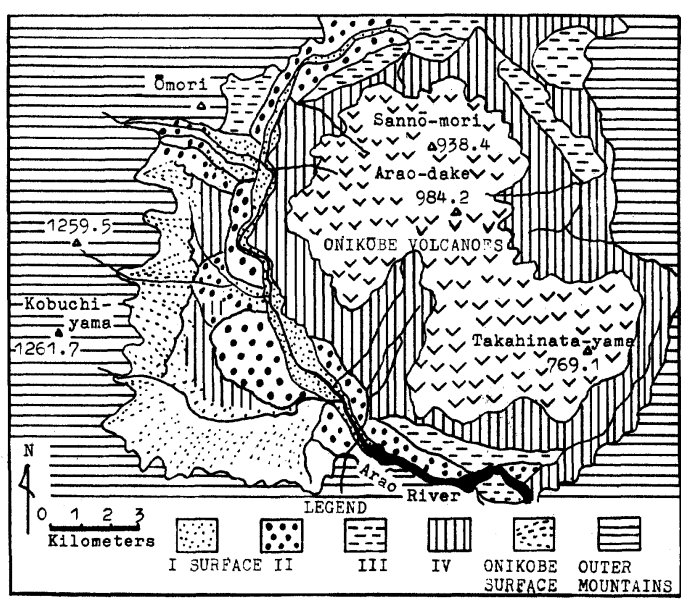

Fig. 7. Geomorphological Map of the Onikōbe Volcanic Area.

about 100 meters from the present river bed.

The brown volcanic ash accumulates on the outer and inner mountains, and also on II, III, IV surfaces. The black volcanic ash cover the brown volcanic ash layer.

\section{Summary}

\section{A. The Narugo volcanic area}

The original form of Kata-numa which seems as explosion crater is supposed to be a paleo-lake formed by the crustal deformation. The mudflow materials and volcanic ashes erupted out under the fluviatilelake environments.

The volcanic ashes from the Narugo volcanoes covered the mudflow materials and terrace plains except the present river bed. These ashes are classified into two main volcanic ashes depending upon the soil colors. One of them is the black volcanic ash, and the other is the brown volcanic ash. The soil color of the black volcanic ash is presumed to have been derived from the colored minerals and humus. 


\section{B. The Onikōbe volcanic area}

The original form of the Oniköbe basin was formed by the crustal deformation, and deposited the lacustrine sediments in the paleo-lake. The first eruption of the volcanic ejecta occurred under the fluviatilelake environments. The volcanic ashes from the Oniköbe volcanoes accumulated on the outer mountains, inner volcanic bodies and terrace surfaces except the present river bed.

However, the volcanic ashes in the Katayamajigoku and Arayu areas include the plant leaves. These ashes are supposed to have been deposited on the bottom of the paleo-lake in early Quaternary age. Under the polarized microscope, no mineral fragments are recognized in these ashes. This is a remarkable point of the characteristics compared with the volcanic ashes of the other areas investigated. This reason is supposed that the alteration of the volcanic ashes has been accelerated by the solfataric action and subterranean heat etc.

\section{Literatures}

Ikeda, T. (1942) Graduation thesis of the Tohoku Univ. (Japanese)
Ishida, T. (1965) Quat. Res., 4, No. 1, 13-21. (Japanese)

Katō, I. and Shimada, I. (1953) Jour. Japan. Assoc. Min. Petr. Eco. Geol., 37, 180-190. (Japanese)

Katsui, Y. (1955) Jour. Japan. Assoc. Min. Petr. Econ. Geol., 39, 190-194. (Japanese)

Kobayashi, F. (1926) Volcanoes. 305-306. Nankōsha. (Japanese)

Miyagi-ken High School's Science Study Organization (1963) Earth Sci. Rept., 1, 18-21. (Japanese)

Murayama, I. (1966) Geogr. Rev. Japan, 39, No. 9, $591-605$. (Japanese)

Nakamura, H. (1956) Monthly Rept. Geol. Surv. Japan, 10, 23-48. (Japanese)

Omoto, K. (1964) Ann. Tohoku Geogr. Assoc., 16, No. 2, 61-70. (Japanese)

537. (Japanese)

Onuki, Y. and Kitamura, M. (1962) Geological map of Miyagi Pref. (Japanese).

Tsujimura, T. (1942) Fault topography. 137. Kokonshoin. (Japanese)

\section{鳴子および鬼首火山地域における第四紀火山灰}

村山勫

日本国土の大部分の耕地土壤は，おもに第四紀火山灰 を母材としている.

この稿では，宮城県の北西部に位置する第四紀火山の 鳴子・鬼首両地域に例をとって，火山灰の堆積・分布状 態，若干の性格などを調査し，これによって耕地土壤の 母材として重要な火山灰の生成過程の 1 例を知ろうと試 みた。

鬼首火山は，構造運動によって形成された構造湖中に 噴出した峠出であり，また鳴子火山の一見火口湖とみら れる潟沼も構造湖とみなされる。これらの地域には，噴 出した火山灰が湖成堆積物となっている個所も認められ る.

一般に降灰当時の火山灰は，黑色または死色系統の土 色を呈するが，風化，溶脱，鉄分の酸化・水酸化などに よって褐色系統の土色に変化していく， その変化の進行
程度は, 降水量・気温・その他の外界諸因子によって異 なる，また地熱地域に堆積している火山兏は，風化，溶 脱の進行程度が大であり，粘土化が著しく進んでいる.

\section{主な地名}

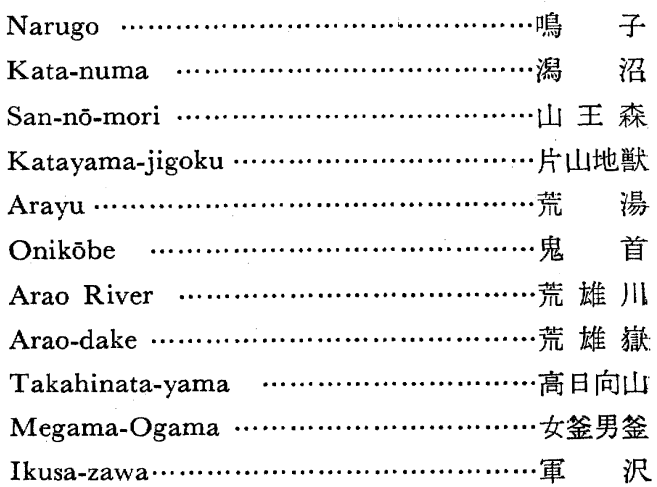

